\title{
Political Power, Collective Memory, and American Central Cities: The Discourses of the Conservative Elite's Counter-Memory of the City
}

\author{
A.J. Jacobs ${ }^{*}$ \\ East Carolina University Department of Sociology 405A Brewster Greenville, NC 27858, USA
}

\begin{abstract}
This study examines the social construction of collective memory regarding American cities. Inspired by postmodern theory, both critical and urban, it argues that, in its efforts to expand its political power, the Conservative Elite has successfully waged a thirty year "mnemonic war" over the public memory of America's central cities. It describes how in their attack, the Conservatives strategically utilized four vehicles of public discourse: political rhetoric, mass media depictions, think tank scholarship, and spatial semiosis. In doing so, the Conservatives have crafted a false consciousness or counter-memory of the city, a depiction which has served to diminish the social and economic value of U.S. central cities, and ultimately, characterized them as Foucaultian heterotopias of deviance (anti-utopias). By recasting the collective memory of the city, the Conservatives have harnessed and defused its historical and present power, squashed any related dissent, and expanded their influence across the metropolitan, national, and international landscapes.
\end{abstract}

Keywords: American Central Cities, post-modern urban theory, collective memory, political power.

\section{INTRODUCTION}

It has been 40 years since America's urban unrest of the 1960s. Even the hardest hit central cities have long since stabilized. Some have even experienced growth. Nonetheless, White Americans continue to flee. Among the 20 most populous U.S. cities in 1980, 13 experienced declines in their White population between 1980 and 2000; four of the top six lost more than 250,000 White residents, including New York's (NYC) which dropped more than 700,000 [1]. This situation coupled with related non-residential disinvestment has caused urban fiscal distress, with many central cities currently unable to meet their rising demands for public services. In contrast, the suburbs continue to extend out further and further from their urban cores.

Of course, none of this is breaking news. In fact, it is important to note here that this study is not intended to be comprehensive review of America's urban problems or its causes. These have been well chronicled by an all-star lineup of scholars. On the other hand, as Beauregard [2] wrote, far too little has been written about the social construction of America's collective memory of central cities, and how public discourse has shaped this memory. Inspired by postmodern theory, critical and urban, this article seeks to fill this void. It reveals how, in an effort to expand its political power, the American Conservative Elite has waged a 30years "mnemonic war" over its nation's public memory of its cities. Drawing on Sperling et al. [3], Smith [4], and Chomsky [5], the Conservative Elite is defined here as the coalition of White political conservatives and free-market ideologues, multinational corporations, the religious right and its adjuncts, the mass media, neo-conservative scholarly think

*Address correspondence to this author at the East Carolina University Department of Sociology 405A Brewster Greenville, NC 27858, USA; Tel: 252-328-1933; Fax: 252-328-4837; E-mail: drajjacobs@yahoo.com tanks, and urban rentiers. This partnership gained a foothold under Nixon and was propelled by Reagan-Bush II minded Republicans, but has also been supported by center-right suburban and southern Democrats [3, 6, 7].

More specifically, it argues that the Conservative Elite has strategically utilized four forms of discourse: 1) political rhetoric; 2) mass media depictions; 3) think tank scholarship; and 4) spatial semiosis (the tools and symbols of real estate development), to re-shape the perceived value of central cities. In the process, they have imprinted a counter-memory or false consciousness of the city in the American psyche, one which ultimately characterized them as Foucaultian heterotopias of deviance. In other words, Americans have been taught to believe that central cities were anti-utopias, penal colonies for undesirables and the polar opposites of the suburbs, the heart of the Conservative power base. By winning the 'mnemonic' battle over metropolitan space, the Conservatives have both diminished the social and economic value of the city and harnessed its historical and present power. This has enabled them to manage dissent and to expand their political influence across the metropolitan, national, and international landscapes.

While many studies have examined one or two elements of this argument, few, if any, have summarized the connections among all four of the aforementioned public discourses. In attempting this, this article hopes to provoke other scholars to re-visit America's perceptions of place and their impacts on central cities.

\section{A BRIEF REVIEW: TYING COLLECTIVE MEMORY, POWER, AND THE CITY}

Halbwachs [8] wrote that collective memory could best be understood as a form of mediated action, involving active agents and cultural tools, both of which influenced public perceptions of the past and present. He believed that societal 
memory was a localized phenomenon, so deeply entrenched in genuine places and social experiences "that place and group each received the imprint of the other" [8]. Taking a far more critical and targeted stance, Chomsky [5] argued that in all Western capitalist democracies, there has been constant tension over the locus of power. He maintained that power elite had addressed this problem in a variety of ways, including utilizing media conglomerates, pseudo-scholarly think tanks, and other adjuncts of government to channel thought and attitudes within acceptable bounds. He claimed that the tendency to rely on such ideological institutions had grown significantly since the 1980s [9]. This, he believed, had allowed the elite to better deflect any potential challenge to their established privilege and authority, before it could take shape and gather strength. It also had allowed them to manufacture consent for a conservative, free market agenda that sought to heighten economic inequality, bust unions, rewrite foreign policy history, and pit physical community versus community $[8,9]$.

Similar to Chomsky, Foucault [10-12] believed that the average person had little input in the creation of collective memory. Rather, each society had its own regime of truth, an apparatus used by the ruling class to manipulate and redefine history, language, and knowledge, in order to impose its own version of social memory. He stated that this system consisted of "the types of discourse, individuals, and mechanisms, such as architectural forms, regulatory decisions, laws, administrative measures, scientific statements, philosophical, moral, and philanthropic propositions," which determined and assigned value to what was accepted and functioned as truth and non-truth [10]. He claimed that this counter-memory enabled the dominant class to: 1 ) further its economic interests; 2) evade responsibility for the consequences of its actions; 3) justify and perpetuate injustices against the masses; and 4) systematically prevent individuals from developing a collective consciousness that might challenge elite rule. His essays 'Panopticism' and 'Of Other Spaces', were metaphors for how the elite had expanded its power by disciplining and stamping its ideology on the city [13-14].

In agreement with Foucault, Giddens [15] argued that within the context of contemporary capitalism, the city was more than just an outcome of social remembrance, but rather an integral and effective medium in the shaping of collective perceptions of the past, the present, and the future. Since he believed that cities were the foundations of capitalist authority and accumulation, by controlling information within the city, including collective perspectives of urban spaces, the dominant class was able to expand its economic and political influence inside and outside the city's territory.

While these critical post-modernists form the foundation of this study's analysis, perhaps the strongest theoretical bridge tying collective memory, political power, and the city has come from the post-modern urban works of Lefebvre and Harvey. While Foucault contended that hegemonic power was maintained through the disciplining space, Lefebvre claimed that the bourgeoisie and its political creation, the State, had appropriated, produced, and then utilized city space as its most important ideological weapon of power [16]. As part of this, he suggested that the capitalists had fostered the development of three kinds of space: ideal or mental space (language and memory); social space (where language became social practice); and real space (the space of social practice, human settlements/political territories). Lefebvre's social space contained three dimensions: 1) spatial practice-"the physical and material flows, transfers, and interactions that occur across space in such a way as to assure [capitalist] production and social reproduction" [17]; 2) representations of space-conceptions of space, knowledge and discourse created by architects, scholars, planners, developers, and technocrats that provide meanings to or offer possibilities for spatial practices; and 3) representational space-spatial semiosis or "the signs, significations, and codes...that allow such material practices to be talked about and understood" [17]. He concluded that since that all three types of space clearly involved, underpinned, and presupposed the other, their intersection tended to generate illusions or a false consciousness of space [16]

Influenced by Lefebvre, Foucault, and Bourdieu, Harvey $[17,18]$ claimed that a structured organization of space has come to exist in the USA. Within this structure, the capitalist class, in concert with the state, the media, and educational institutions, has produced and defined spatial practices, representations, and urban spatial structure, in order to sustain their privileged position. These prescriptions then shaped the average American's image of the spaces in which we lived and did not live. Applying Bourdieu's [19] theory of structures, habitus, and power, he argued that by assigning collective value and meanings to spaces, contemporary capitalism determined both the organization of spaces within American households and within urban areas. He claimed that within this context, the capitalists had crafted a realized myth of geographic places and had utilized it an "essential ideological ingredient of social reproduction" and power [17].

Inspired by Lefebvre and Harvey, Boyer maintained that when the power elite have seen benefits in investment in the city, they have invested. Over the past few decades, however, whenever a city was seen as not producing a profitable enough return, they have quickly abandoned it for the suburbs, and then defended their new investments by forcefully redefining the image and value of disinvested city spaces [20]. Similarly, in his work on urban semiotics, Gottdiener wrote that collective representations of the city have served as mediators of behavior, attracting, repelling and directing our actions and settlement patterns. He said that the real estate industry has produced a formidable quantity and variety of spatial semiosis that have dramatically shaped the collective reputations of each city. He defined spatial semiosis as verbal and non-verbal signs and images that imprinted symbolic meanings on urban spaces [21-22]. Fifty years ago, Wohl \& Strauss [23] called these semiosis the "persuasive propaganda" that symbolically characterized a particular community, psychologically, as well as physically.

Other post-modern urban writers, such as Beauregard, Smith, Davis, and Soja, on the other hand, have maintained that political rhetoric, mass media accounts, and government reports have built an extensive case against the collective image of American central cities [2, 4, 6, 24-26]. They stated that as a contested space, the city has always engendered fear that was derived from the sense that it represented uncontrollable space. They claimed that contemporary perceived fear of the city has become more powerful and accepted than 
reality, and that politicians' and the media's over focus on homelessness and random violence has heightened this sense of anarchy. They suggested that, right or wrong, as a consequence of these perceptions, Whites have continued to flee the city for the imagined safer, more orderly spaces of the suburbs. As Davis pointed out that, since around 1992, the majority of Americans have lived outside of central cities. As a result, the collective perceptions of a large and growing percentage of White Americans regarding central cities and inner city people have been shaped by elite characterizations, rather than by actual experiences [6].

Overall, similar to the critical post-modernists, Chomsky, Foucault, and Giddens, the post-modern urban theorists have contended that the power elite, which since the 1970s, has been dominated by neo-conservatives, has utilized three public discourses: political rhetoric, media depictions, and so called expert narratives, to push its anti-urban, countermemory of the city. In addition, as Boyer, Gottdiener, and Wohl \& Strauss suggested, spatial semiosis, (i.e., the symbols and tools of real estate development), have been a fourth public forum utilized by the elites to shape collective perceptions of the city. To take a most critical view, it could be argued that the elite have sought to turn the central city into Foucaultian heterotopias of deviance: anti-utopian penal colonies for the poor, minorities, and others that the Conservatives defined as deviant, and who should be set apart from the general population. By destroying the economic and social value of the center city, they could then emasculate a major stronghold of resistance to their power and privilege.

Drawing on the aforementioned post-modern theories and others, the following sections demonstrate how, over the past 30 years, the Conservative Elite has naturalized their counter-memory of the American central cities through the four major public discourses.

\section{WEAVING A COUNTER-MEMORY THROUGH PO- LITICAL DISCOURSE}

During the 1960s, the liberal wing of the Democratic Party was in full command of the American political agenda [7]. The base of their power was large central city mayors from the industrial north, minorities, and organized labor. Much of the south also voted for the Democrats, due to their distaste for the Republican Party, dating back to Abraham Lincoln's stance against slavery. Perhaps tired of the social unrest of the times, American public opinion began to shift toward the center, beginning with the election of Richard Nixon in 1968. However, by the mid-1970s, the Republicans were in need of an image overhaul, stinging from Watergate and seen as dominated by the interests of the affluent and big business. This allowed the Democrats to temporary regained the White House in the 1976 election, albeit only doing so by turning to a relatively Moderate-Conservative Southern Democratic, Jimmy Carter. The Carter Administration, however, was doomed to fail, as it took office in the latter half of a decade of unprecedented high rates of inflation, interest, and unemployment.

As public discontent grew, hard-line conservatives, utilizing overt rhetoric-laissez faire economics, deregulation, privatization, smaller government, lower taxes, and balanced budgets- and coded-language- tough on welfare, drug abuse, and inner city crime- seized control of the Republican Party, and more importantly, the collective political discourse [7]. The result, beginning with the 1980 Presidential election, was the creation of a cross-class, neo-conservative popular movement that aligned the traditional adversaries of the White working-class with corporate America, against the anti-poverty and inclusiveness programs of the Democrat New Deal and Great Society [7].

The new Republican agenda was greatly aided by changing demographics in American cities. By 1980, the populations of New York City, Los Angeles, Dallas, and Houston had become $39 \%$ non-White, with higher proportions in Philadelphia, San Francisco, and Memphis (all 42\%), Cleveland $(47 \%)$, Chicago $(50 \%)$, Baltimore $(56 \%)$, New Orleans $(57 \%)$, and Detroit (66\%). Several of these cities also had elected Black Mayors. Over the next 20 years, the White population declined in seven of America's ten largest cities, excepting Dallas, San Diego, and Phoenix, in the respective home states of the Bushes, Ronald Reagan, and ultraConservative Chief Justice of the Supreme Court, William Rehnquist [1].

Considering the dire economic conditions, it was not surprising that many Whites temporarily changed their party affiliation for the 1980 election. However, in order to turn this into more than a short-term switch, the Conservatives had to provoke lasting attitudinal changes among working and middle class White suburbanites. This was accomplished by an almost daily attack, by the Reagan White House and its agents, on the ideals and power-base of the Democrats: organized labor, Blacks, the poor, central cities, and redistributive programs that aided them.

Growing residential segregation by race and class made the task fairly straightforward: Conservatives simply had to create a new regime of truth that exaggerated and pinned all of America's ills on unions, central cities, and poor minority urban residents. By constantly driving a wedge deeper into the already tense racial and city-suburban conflict, they were then able to plant, in the psyches of White suburbanites, the idea that they should distance themselves completely, both geographically and socially, from the ever dangerous central cities [27]. Once legitimized, the Conservative attacks became accepted by the White working and middle class, as normal, even righteous. Voting for neo-Conservatives, especially for President, became the only proper choice in which to protect the U.S. Constitution, the American economy, and "the moral fiber, personal well-being, and security of ordinary citizens" [7].

According to Sperling et al. [3], the Republican Conservative coalition developed, continually perfected, and branded their own distinct and straightforwardly defined policy agenda. They then aggressively sold this 'brand' to Americans through the political rhetoric of hate and public policy decisions geared toward exacerbating existing divisions among Americans. A special focus of this assault was a form of Social Darwinism, which pitted the predominantly White non-metropolitan and suburban parts of the USA and the Sunbelt (South and West), against the relatively diverse, densely populated central cities of the industrial north/Rustbelt, formerly prominent during the country's era of heavy manufacturing [3, 28-30]. In other words, under Reagan 'New' Federalism, the U.S. Government essentially promoted fierce inter-local and inter-regional competition, 
and then, implemented policies and programs that clearly favored their constituency, while diverting investment away from the Democratic base [28]. On this uneven playing field, heightened competition essentially served to diminish the social and economic of older central cities, which were already suffering from fiscal distress [29].

Davis claimed that this post-1980 political context has had several epochal consequences. Most damaging was the complete "semantic merging of race and urbanity within US political discourse: 'Big City' was now a euphemism for the Black-Latino underclass" [6]. He said that the watersheds in this metamorphosis were 1980, when suburbanites become the majority of the White electorate, and 1992, when suburbanites became the majority American voters. These events "greatly simplified the geography of partisan politics: Republican Party affiliation was now a direct function of distance away from urban centers" [6]. Congressional district reapportionment has further reinforced this split: since 1980, central city representation in the U.S. Congress has declined from one-quarter to less than one-fifth of the seats $[3,6]$. As result, it was possible for Conservative Republicans to win the White House several times while being swept in America's largest cities. This basically provided Conservatives with political autonomy from the crisis of America's core cities. It also provoked fundamental change in the Democratic Party [3, 6, 27].

Following Walter Mondale's loss to Reagan in 1984, a decade-long battle for the Democratic Party ensued, pitting conservative Southern and suburban Democrats versus labor, big city mayors, and civil rights groups. At the forefront of this shift, was the Democratic Leadership Council (DLC). Founded in the mid-1980s by Al From, the DLC set out to re-shape the Democrats into a progressive centrist party, and energize it with "A Third Way for governing, based on progressive ideas, mainstream values, and innovative solutions that reflect changing times..." [31].

The new agenda helped put Bill Clinton in the White House in January 1993. Ever since, Democrats have been careful to regularly reassure White suburbanites that they were not soft on crime or tolerant of big-city welfare expenditures $[3,6]$. If they did not, they lost. Moreover, although they have stressed empowering the poor, when discussing urban issues, they have advocated several neo-Conservative Republican policies, such as enterprises zones, community policing, school vouchers and charter schools, privatization of public housing, tax cuts, market incentives for environmental protection, and welfare reform [2, 6, 31]. While no one would characterize Clinton as a Reaganite, evidence suggests that the 1992 election was a clear sign that even the Democrats had capitulated to the neo-conservative countermemory of the city. In fact, many in the popular media have maintained that the Democrats only re-won the Congress in 2006 by turning to Conservative candidates [32]

Along with the Reagan, Bush I, Clinton, and Bush II presidential races, surveys, as well as Congressional and state elections suggest that the Conservative's countermemory of the city has become a part of American culture. Americans now more than ever before favor tax cuts and reductions in government aid to disadvantaged people and places, even if it benefits them [3]. However, political rhetoric was not only form of public discourse utilized by the
Conservatives in their effort to weave a false consciousness of the city. It is just the most discussed in the academic literature. The popular media, both visual and print depictions of the city, have also played an important role in their strategy.

\section{THE MEDIA AND THE CONSERVATIVES COUNTER- MEMORY OF THE CITY}

Sage [33] claimed that because the mass media was such a ubiquitous part of our lives, it has feverishly worked to convince us that it reports were factual, unfiltered, and objective. Media productions, however, are mediated narratives, ideological driven reports of news, programs, images, and other information that significantly shape popular culture, collective perceptions, values, attitudes beliefs, and consensus $[18,33-35]$. Among other things, they have helped legitimize, domestic and international social, political, and economic inequality, and instilled what was acceptable, healthy, normal, and good $[5,9,20,35]$. Although the internet is now threatening its primacy, since the 1960 KennedyNixon debates, television, due to its ability to transmit powerful images, words, settings, and sounds, has been the kingmaker of constructed meanings [34].

As the American mass media has grown in size and importance, especially since the 1980 s, ownership of its outlets has become more and more concentrated in the hands of large corporations. As a result, bottom-line considerations have gained far greater influence over programming and news than ever before $[9,33]$. According to Herman \& Chomsky [9] this, combined with the decline of public broadcasting and a reduction in resources devoted to journalism, has made the media more dependent for information, on both those who make, and subsidize the news. Within this context, the media then has been expected to express opinions that supported the interests of the state, and the corporate elite, and:

\begin{abstract}
To do so with enthusiasm and optimism about the causes in which [it was] engaged. If one of those causes ... [was] to act as vigilant guardians protecting privilege from the threat of public understanding, the media [has resorted] to 'necessary illusions,' carefully selecting the framework in which issues ... [were] discussed, raised, and premises left unmentioned [5, 20].
\end{abstract}

In addition, while Conservatives have frequently complained about a liberal media bias, in reality, media consolidation, combined with post-1980 changes in geo-politics and global capitalism, has enabled them to establish ideological hegemony over the marketplace of ideas and to manufacture consent for their agenda [5, 9].

Perhaps the best illustration of this has been post-1980 media depictions of the city and the suburbs [20]. As Boyer wrote, its "disassociating of the images of uneven development from those of place and privilege [the media has] allowed unmentionable inequities to be sustained as normal and inevitable consequences of economic growth and global pre-eminence" [20]. In the process, it has left little room for critical dissent against the Conservative message of the city, regardless of actual conditions. "For example, on balance, NYC is the recipient of more negative feelings than positive 
ones among media 'experts' or influentials, and most Americans would object strongly to living there. Yet, it is the wealthiest city in the USA" [21].

Of course other cities besides New York have also experienced the wrath of the media negative depictions of the city. In his books on Los Angeles, Davis [5, 25] claimed that the L.A. Police Department has, over many years, utilized the local press to exaggerate crime statistics and invoke "racialized crime scares" to strengthen its position in the city. He suggested that, in its thirst for ratings and copy, the local media has supported this strategy by sensationalizing the connection between street gangs, violence, and international drug cartels in L.A. and Miami. This has included newspapers exposés which have characterized the city as 'Cartel L.A.,' overrun by cocaine warehouses manned by legions of extremely loyal Colombian henchmen, and article series informing readers about how the L.A. street gang, 'the Crips', controlled the city's streets and dominated the rock cocaine trade in 47 cities through murderous violence [25].

While some scholars have questioned the legitimacy of Davis' works, there have been countless other Conservative attacks on central cities through the media. One journalist, who authored a popular 1993 book on urban decline, typified the media's bombastic use of negative imagery to sell their product. In describing a Detroit neighborhood he wrote:

\begin{abstract}
What remains is something worse than a slum. A scattering of once beautiful, now hopelessly decayed mansions stand within...a wilderness of rubble, all but hidden behind ranks growths of Midwestern weeds. Remaining denizens come and go...in a fog of drugs, crime, and hopelessness. So desolate is this neighborhood that you can stop at an intersection of Woodward looking straight downtown past the boarded-up storefronts toward the towers of the Renaissance Center and not see a single automobile ahead or behind you [36].
\end{abstract}

Beauregard [2] wrote that the mainstream media has always offered exaggerated characterizations of the city, both good and bad. What has changed since the 1980s, however, was the incredible rise in the proportion of such accounts that described central cities as obsolete, beleaguered, crime ridden, and frightening places on the verge of disintegration. Conversely, he said, the media has carefully ignored the ills of the suburbs, almost invariably depicting them as the home of the Great American dream, progressive, safe, harmonious places, filled with fresh air and wide open spaces. In other words, it has taken an active role in instructing White Americans to stay in the suburbs and away from the city. He concluded that media had done its best to ensure that: "In America, the cities can never win" [2].

Of all forms, however, the visual media, with its powerful images of inner city crime, looting, and rioting, in cities such as Detroit, L. A., Miami, and Cincinnati, has provided the Conservatives their best medium to naturalize their counter memory of the city $[2,4,6]$. Hollywood's glamorization of the worst ills of the city, in such films as, Fort Apache the Bronx, the Warriors, the Substitute, New Jack City, Bonfire of the Vanities, and Grand Canyon, and in TV shows and mini-series, such as Hard Copy, 911, and The
Corner, among others, has forcefully ingrained in the social memory, the conception that America's largest central cities have become Foucaultian heterotopias of deviance, prisons without walls, controlled by gangs, drug addicts, and other miscreants, and occupied by minorities, immigrants, the poor, the homeless, and other disadvantaged groups deemed inadequate by the right $[2,4]$.

Whether the mass media is truly liberal or right wing biased is an argument for another day. Nonetheless, whether motivated by the desire to report factual events or to merely improve its ratings, its constant focus on urban crime and poverty has clearly supported the Conservative's crafting of their counter-memory of the city. These depictions have helped reinforce the tendency among Americans to associate the country's worst social problems with the city [37]. So much so that surveys now show that even when confronted with data showing positive changes in the city, the majority of White Americans freely admit that they are simply too afraid to live or raise their families in central cities [38]. In response, they continue to seek refuge in the ever more distant suburbs, places they have been taught to believe are devoid of societal troubles, and governed by 'traditional family values'. One constant source reinforcing this false consciousness has been the narratives of quasi-expert Conservative think tanks

\section{THINK TANKS AND THE COUNTER-MEMORY OF THE CITY}

So-called scholarly think tanks have been a part of the American policymaking scene since at least 1916, when the Brookings Institution was founded. Yet, their numbers have grown remarkably since the late-1970s, especially those known as, Advocacy Think Tanks [39-42]. Most of the roughly 1,600 think tanks claim to be non-partisan [39]. On the other hand, Advocacy Think Tanks have actively pursued agendas. While a relatively small number have been 'left-leaning', dozens have promoted the causes of the right [40].

In fact, so many conservative intellectuals had descended on Washington by the early 1980 s that veteran political journalists began to speak of a new 'ideas industry' and to assess the role that conservative think tanks, such as the Hoover Institution, the American Enterprise Institute, and the Heritage Foundation had played in the Reagan's victory [41].

While individually, Conservative think tanks would find it difficult to attract a receptive audience, collectively, their sheer numbers has "enabled their supporters to...popularize initially radical ideas and policies, and project them to a much broader audience" [43].

According to Abelson [39], Soley [40], and Rich [42], Conservative think tanks have flourished in large part because they have been afforded a great deal of free publicity, creditability, notoriety, and policymaking legitimacy by the popular media. This has allowed Conservative politicians to quote their conclusions as if they were completely and objectively factual. In turn, beginning with Reagan, the Conservatives have offered their cadre of so-called policy experts a frontline role in their mnemonic attack on the Democrat's base, including central cities. 
Among the three conservative think tanks mentioned in the earlier quote, the Heritage Foundation, founded in 1973, is the largest and most well known. At $\$ 48.34$ million in 2007, its operating expenses exceed that of the combined total of all of left-leaning think tanks [43-44]. It claims 320,000 donor members, including numerous top executives of Fortune 500 companies, several Reagan and Bush appointees, and Rush Limbaugh, the self-professed radio voice of Conservative America [44]. Its Executive Vice President is a former staff member of Strom Thurmond, the staunch anti-civil rights 'Dixiecrat' turned Republican senator who initially became famous when he carried four states in the 1948 Presidential election, running as the nominee of the segregationist, States Rights Democratic Party [45].

Heritage's mission is "to formulate and promote conservative public policies based on the principles of free enterprise, limited government, individual freedom, traditional American values, and a strong national defense" [44]. Former House Speaker, Newt Gingrich, credited Heritage with leading the Conservative's charge to win the "the war of ideas" in Washington [42]. President Reagan believed so strongly in their agenda that he adopted their motto in his policy making: "Ideas have consequences, rhetoric is policy, and words are action" [41].

Robert Rector's [46] 'A Comprehensive Urban Policy: How to Fix Welfare and Revitalize America's Inner Cities,' represents a prime example of Heritage's right-leaning urban policy papers. In this document, he recommends solving America's urban problems by ending welfare, improving inner city education through private competition, revitalizing central cities through the restoration of moral values and personal responsibility, substantially expanding spending on prison construction, and toughening prison sentences. He suggests that urban America was destroyed by a welfare system that taught the poor to behave immorally. He claims that any statistical evidence showing that there is widespread urban poverty and hunger, malnutrition, and overcrowded substandard housing, is merely 'liberal propaganda'. He maintains that there is little material poverty in the USA. Rather, what exists is what

\begin{abstract}
Might be called 'poverty of the spirit', behavioral poverty... a breakdown in the values and conduct which lead to the formation of healthy families and communities, stable personalities, and self-sufficiency. It incorporates a cluster of social pathologies, including: eroded work ethic and dependency, a lack of educational aspiration and achievement, the inability or unwillingness to control one's children, increased single parenthood and illegitimacy, criminal activity, and drug and alcohol abuse. While material poverty may be rare in the United States, behavioral poverty is entrenched and growing [in its inner cities] [46].
\end{abstract}

Established in 1943, American Enterprise Institute (AEI) was relatively unknown prior to the 1970s [42]. AEI's stated purpose is "to defend the principles and improve the institutions of American freedom and democratic capitalism, [including] limited government, private enterprise, individual liberty and responsibility, vigilant and effective defense and foreign policies, political accountability, and open debate"
[47]. Similar to Heritage and Hoover, AEI has far from promoted open debate on most issues. Its experts have published numerous reports blaming the decline of urban America on inefficient and ineffective Liberal Democrat-led governments and a culture of poverty among inner city Blacks.

A typical prime example of an AEI policy paper is Joel Kotkin's 'Ideological Hurricane' [48]. Commenting on the extent of the tragedy in New Orleans following Hurricane Katrina, Kotkin blames New Orleans' failure to evacuate in time on 'rotten' liberal city and state administrations, and the deficient attitudes of its residents. He says the latter, similar to in other cities, continue to promote an "urban culture of economic and cultural attachment... a culture of poverty and social dysfunction [48]. In addition, he argues that "rather than improving conditions for the average residents of their cities, [liberal] urban and federal politicians, and [their] interest groups, have promoted policies that have actually exacerbated a metastasizing underclass" [48].

As for the Hoover Institution, although independent from Stanford University since 1959, it is now considered America's most influential on-campus Conservative think tank [42]. Perhaps more than anything else, this is because it is housed at the elite and exclusive private university, a major launching pad for Silicon Valley [40, 42]. Hoover's mission is to collect, generate and disseminate knowledge and ideas, while defending the American Constitution, the free enterprise system, and the principles of individual, economic, and political freedom, including limiting government intrusion into the lives of individuals [49]. In its publication, Policy Review, Hoover scholars regularly rail against programs supporting the poor, the disabled, and cities. This agenda is not surprising considering its board and major donor list is comprised of Fortune 500 executives, Wall Street investment firms, and the country's largest communications conglomerates, among others. The latter includes News American Corporation (Fox), whose national news programming styles itself as the most vigorous defender of Conservatism on U.S. television.

In sum, by regularly linking liberal politics, minorities, poverty, crime, and other social disorders to cities, and to one another, think tanks have played a vital role in naturalizing the Conservative's counter-memory of the city $[37,50]$. Of course, their message would not have been as readily accepted, if not for their deploying of the powerful tools and signifiers of real estate development.

\section{THE SPATIAL SEMIOSIS OF REAL ESTATE DEVE- LOPMENT AND THE CONSERVATIVE COUNTER- MEMORY}

Spatial semiosis represent the final public discourse utilized by the Conservative Elite to craft their false consciousness of the city. Drawing on Gottdiener's [21-22], Wohl \& Strauss' [23] Foucault's [10-12], Beauregard's [2], and Lefebvre's [16] three aspects of social space, spatial semiosis are defined here as the symbols and tools of real estate development, such as architectural and physical forms (including infrastructure), land and building regulations, development designs (such as subdivisions), real estate practices, signage, and real estate narratives, both printed and verbal, which convey meanings and shape collective perceptions and the social and economic value of places. 
Expressways and major arterial roadways which either physically separate the central city from the suburbs, or which divide a city or region into cells, are examples of what might be called covert or latent spatial semiosis. Two good illustrations of their effectiveness in shaping collective perceptions of the city are Detroit's Eight-Mile Road and Interstate-696. On the northern border of the City of Detroit, Eight-Mile is frequently referred to by locals as the DMZ, a reference to the $38^{\text {th }}$ parallel demilitarized zone separating North and South Korea. In Metro Detroit, however, it signifies the post-1970 accepted barrier between city and suburb, and between Black and White Detroit [51-52]. As for I-696, although its first section was opened in 1962, White suburban opposition held up the expressway's completion for more than 15 years. Located approximately three miles north of Detroit, it was only after urban decline and the Black population began encroaching north of the central city's corporate limits, that its eastern third between I-75 and I-94 (completed in 1979), and its middle section between Telegraph Road and I-75 (opened in December 1989), were approved. Local officials south of the highway now fear it is slowly becoming the new dividing line between the region's 'haves' and 'have nots' [52].

Token skyscrapers represent another latent spatial semiosis in the Conservatives' playbook. How could a new office tower damage the image of a city? Detroit's Renaissance Center is a perfect example. With its large front yard berms, maze-like corridors, and security guards, access to the complex is completely controlled, preventing intrusion from unwanted outsiders. Meanwhile, the infrastructure in nearby residential neighborhoods continues to deteriorate unabated. Such benign neglect in itself stands out as a symbol/tool of elite distain for the central city. However, devoid of further adjacent redevelopment and any real commitment to central city revitalization, the 'Ren Center', and other token fortresses like it in the U.S., set as 'islands in seas of decay' [53-54]. As a result, rather than providing their intended white refuge from the inner city, their stark contrast with the surrounding area actually serves to magnify the sense of impending danger, especially among suburban Whites with little to no first-hand interaction with city residents. This mix of images has then further discouraged reinvestment downtown, and left the Ren Center, for most of its history, half empty.

Detroit is not the only city to have been negatively impacted by half-hearted urban redevelopment. In fact, it could be argued that inner city neighborhood gentrification, in general, has been more tokenism or 'for show' than any concerted urban revitalization effort $[2,4,25,55]$. While the academic literature continues to debate the extent of minority displacement directly caused by gentrification, similar to expressways, when such projects have displaced poor minority residents, the net loss in affordable housing supply has unquestionably intensified overcrowding in remaining low-income central city neighborhoods [25, 53-60]. Constant post-1980 Conservative Presidential Administration and Congressional funding cuts to U.S. Housing programs have exacerbated this situation, by lessening the likelihood that replacement affording housing was constructed [55, 59]. Spot gentrification also has sometimes encouraged the abandonment of other nearby lower-cost properties. In the process, surrounding neighborhoods decay in wait, harming the overall image of the city $[54,61]$.
Another facet of the Conservative gentrification smokescreen concerns myths about who the really gentry are. Studies show that residents of gentrified properties are, more often than not, already city dwellers, merely relocating to better accommodations [56, 59, 62-63]. In more than half the cases, the gentry are middle-class Blacks, immigrants from Asia and Latin America, gays, liberal academics, artists/bohemians, or others who are critical of the status quo [4, 61, 64-66]. None of these groups are viewed by Conservative Elite as part of their coalition or constituency. In other cases, rentiers may be merely acting as the Conservative's protector of a symbolically important or prestigious space in the city, or reclaiming it from the 'other.' Examples of this include historic or waterfront district redevelopments that are meant to appeal to tourists, rather than city residents $[4,65,67]$.

Overall, despite claims of a growing 'back-to-the city movement', gentrification clearly "affects only a small fraction of the central-city housing market, and is dwarfed by continued metropolitan/suburban expansion" [68]. The fact that the White population declined in 13 of America's 20 largest cities between 1980 and 2000, supports this position. Moreover, the bulk of gentrification has occurred primarily in only a few cities, particularly, New York, Chicago, and San Francisco. Conversely, in most other older central cities, especially Detroit, Cleveland, and Philadelphia, where the city has Black and/or Democrat leadership, there has been relatively little re-investment, with the exception of sports stadiums [37, 53-54, 67-70]. These three cities lost a combined 530,000 Whites after 1980, and almost as many jobs. Even in NYC, the lion's share of private-rentier led gentrification has focused on serving Manhattan or workers from Wall Street's financial sector, the ultimate symbol of post1980 Conservatism [61, 67, 71].

As for the use of what might be called overt spatial semiosis by the Conservatives, a prime example is the deliberate neglect of rental properties by absentee landlords. Such actions frequently induce further delinquency, vandalism, and abandonment, with rapidly falling valorizations making even structurally sound neighboring properties unprofitable and potential threats to arson $[4,6,24]$. When abandonment spills over into several inner city neighborhoods, it ultimately fosters what Smith called a 'ground rent gap', in which the overall market value of property in the city falls far below its true potential value [4]. This then even affects relatively stable working class inner city neighborhoods, especially those populated by minorities. In contrast, fear induced demand for safe havens grossly over-inflates property values in the suburbs [2, 4-6, 23-27]. Combined, this situation has not only padded the pockets of rentiers, but it also has enlarged the Conservative's political base.

While many spatial semiosis have occurred within cities, some of the most significant utilized by the Conservatives have appeared outside the city. As Gottdiener wrote, once businesses and homeowners have decided to locate within a particular region of the country, businesses will select a locality to operate in based upon a variety of issues, including market accessibility, taxes, and infrastructure subsidies [21]. On the other hand, homeowners principally are "concerned with housing values, the quality of schools, crime, tax rates, and the size of a home for its cost...Here, the image that a particular place possesses becomes critical in the competition 
for resource-producing as opposed to resource-draining residents" [22]. The local development tools of zoning and subdivision regulation have helped to shape such perceptions.

Rigid, narrowly defined, single-purpose zoning and subdivision ordinances have clearly promoted and naturalized the conception that owning a single-family detached house on a large lot (one acre or more) was emblematic of capturing the American Dream. It also signified to others that a family/individual had achieved successful entrance into the bourgeois class [27]. In contrast, such regulations have generally disfavored multi-family complexes, while prohibiting manufactured homes and mixed-density developments. Combined with institutional racism in mortgage lending, this situation has effectively defined apartments as the housing of failure, renters as lower-class 'city' citizens, and places with large amounts of rental units, i.e.., central cities, as heterotopias of deviance.

'Gated' communities, or residential enclaves where community access is regulated by walls, fences, gates, and private security, represent another fear-induced suburban spatial semiosis $[22,72]$. Principally a Sunbelt phenomenon in the past, with the largest concentrations in Los Angeles, Houston, Phoenix, and Miami, since the 1990s, similar developments have spread rapidly even in the mid-sized regions of the Midwest, such as St. Louis and Cincinnati. Moreover, similar to large lot subdivisions, gated communities once merely stood as fortresses of elite exclusivity. However, they have now become, more than ever before, security zones constructed to protect upper and upper-middle income Whites from the city and 'urban' people' (i.e., minorities) [72]. So much so, that, according to the U.S. Census Bureau's 2007 American Housing Survey, today, more than five million of America's 52 million suburban households are located in such secured communities. This represents a 25 percent increase from just 2001 [73]. Although they are becoming more diverse, since most of these islands are overwhelmingly White their recent dramatic expansion nation-wide is but another vivid symbol of White America's growing collective acceptance of the Conservative's false consciousness of the city.

A final set of powerful spatial semiosis benefiting the Conservative agenda has related to state laws regulating local government formation. With Conservatives at the national level preaching decentralization, smaller government, and local control, Conservative local politicians have taken advantage out-dated state laws, many pre-dating an advanced urbanized society, to produce wide-scale metropolitan fragmentation in the USA $[29,35,38,48,50]$. The net result has been the incorporation of thousands of tiny, racially and class exclusive suburban republics, most with substantial administrative and financial autonomy. This has broken the hold on state and regional politics once commanded by allpowerful big city mayors, even in the industrial north. Again, Michigan, with 1,776 cities, villages, and townships, is the perfect case study of this.

Detroit, which at one time contained almost two millions residents, is Michigan's largest city. Nevertheless, under state law, with the exception of some special taxing powers, its authority is basically identically to that of the state's other cities. This includes the City of Lake Angelus, in its northwest suburbs, with only 326 inhabitants. Metro Detroit alone contains more than 300 municipalities, including numerous small home-rule villages and charter townships, all with legal boundary protection against city annexation. Among the latter group are highly urbanized communities, such as Clinton (population 95,648), providing similar services to the region's cities. The only difference is that they have refused to legally incorporate as a city $[29,52,70,74]$. Why? When asked, local officials have generally responded that they decided to become a Charter Township rather than a city primarily for two reasons: 1 ) in order to gain boundary protection from adjacent cities; and 2) because of the perceived negative image that the term "city" would connote to their residents and outsiders. These local leaders firmly believe that if their jurisdiction was known as a 'City', middle and upper middle income Whites would rapidly flee for another locality [52].

How has the word 'city' come to evoke visions of heterotopias among politicians and citizens in places like Michigan? From a critical perspective, it could be argued that there has been a concerted and purposeful political effort in America to devalue its cities [75-76]. Spatial semiosis, along with political rhetoric, media characterizations, and think tank scholarship have been the powerful tools of discourse utilized by the Conservative Elites to weave such a countermemory of the city. Their mnemonic victory has then allowed them to harness the historical and present power of the city, and in the process, squelch any potential dissent to their political agenda. The net has been a great expansion of their power across the metropolitan, state, national and international political landscapes.

\section{COLLECTIVE MEMORY AND URBAN SPATIAL STRU- CTURE IN THE USA}

Far too little has been written about America's collective memory of the city, especially in-depth investigations into how the various public discourses have shaped perceptions. Drawing on post-modern theory, critical and urban, this article sought to help fill this void. It argued that for roughly 30 years, the American Conservative Elite have waged a "mnemonic war" over their nation's memory of the city. It showed how, in their efforts to expand their political power, they have utilized the discourses of political rhetoric, media portrayals, think tank research, and the spatial semiosis of real estate development, to construct, brand, and naturalize their false consciousness of the city. Their victory has served to diminish the social, economic, and intrinsic value of central cities, and ultimately painted them in the public eye as Foucaultian heterotopias of deviance: anti-utopian colonies for those the Conservatives have deemed undesirables. Meanwhile, by constantly contrasting the city with the suburb through the four public discourses, the Conservatives have also cultivated what Fishman [27] called, a bourgeois utopian illusion of the suburbs. The combination has enlarged their constituency, won over conservative Democrats, and significantly weakened the historical and present power of the city, an important part of the liberal base. The end result has been a significant expansion in Conservative influence at all political spheres and scales.

For critical memory theorists, the Conservative's naturalizing of a counter-memory of the city, during such a tumultuous period in American history, would not be surprising. These scholars have suggested that individual and societal conceptu- 
alizations of places and events have often been fragile and subject wholesale changes during times of distress [77-78]. Despite its predictability, the magnitude of the Conservative's accomplishment should not be diminished. In fact, evidence suggests that because of it, America's perceived collective image of places, and how they are viewed by locals and outsiders, may have now surpassed accessibility as the prime influence on an area's inherent and economic value [79].

In other words, unlike anywhere else in the world, American central cities, despite their extensive transportation and utility networks, and their dense concentrations of population and employment, are no longer viewed as the most attractive locations for private investment and opportunity. Of course, there are some exceptions to this, such as Manhattan, Boston's Financial District, and inside the Chicago Loop. At the very least, since more than half of Americans now lives in the suburbs, and the fastest growing suburbs are among the most Republican areas of the country, it is not farfetched to suggest that a large and increasing segment of the U.S. population has come to internalize the Conservative's new semiotics of place [80]. In some parts of the America, even the term 'city' has become quasi-demonized.

What is perhaps most deleterious about this situation is that most Americans seem to accept as a given, that there is nothing wrong with the fact that the poor and minorities live in deteriorating and dangerous inner city neighborhoods. It has somehow become part of their psyche that the people who inhabit such places are supposed to live in such heterotopias. Two generations of Americans now have been raised in this societal context. That means that every year fewer and fewer realize that for most of American history, the city was not what they now envision it to be. Even fewer probably realize that in every other part of the world, the central city remains the most desirable locations for people to live, work, and play, if they can afford to. Even in neighbouring Canada.

The theory guiding this article was somewhat unconventional for contemporary urban scholarship. Moreover, the method of analysis utilized was more descriptive than anything else. As a result, some may take issue with its conclusions. While they may have not been proven with inferential statistics, anecdotal evidence suggests that they may now ring true. If they were completely untrue, and if we truly still valued our central cities, we surely would have embarked upon a much more diligent effort to revitalize them than we have, over the past 30 years, would we not? Critiques aside, it is actually hoped that this study sparks other scholars to test the validity of its contentions using quantitative methods. Such analyses would certainly provide valuable new knowledge on the topic. On the other hand, researchers may find it difficult to statistically control for current local, regional, and national contextual factors. Cross-national comparisons may be helpful in this respect. Such studies should also reveal how incredibly different our perceptions of cities are from those of residents in other developed nations, and how American political economy has played a vital role in these divergent conceptions.

In closing, the time is ripe for new ways of thinking about things. In the midst of the country's most dire financial situation since the Great Depression (i.e., the current sub-prime, stock market, and housing turmoil of 2008), we must begin to think 'outside of the theoretical box' if we are to truly understand and improve the conditions of our central cities. For, if
Americans cannot recast their collective image of the city, efforts to reinvigorate them will never have more than a minimal effect. That is, unless a massive back to the city movement becomes in the best interest of the Power Elite. But then, where will they send those they consider to be the 'other', to the suburbs?

\section{ACKNOWLEDGEMENT}

The author would like to thank the anonymous reviewers and Ms. Sadia Manzoor at TOUSJ, for their comments and guidance related to the article.

\section{REFERENCES}

[1] US Department of Commerce, Bureau of the Census. Online [Retrieved on April 23, 2006] Available from: www.census.gov

[2] Beauregard R. Voices of decline: The postwar fate of U.S. cities, $2^{\text {nd }}$ ed. NY: Routledge 2003.

[3] Sperling J, Helburn S, George S, Morris J, Hunt C. The great divide: Retro vs metro America. Sausalito, CA: Polipoint Press 2004.

[4] Smith N. The new urban frontier: Gentrification and the revanchist city. NY: Routledge 1996

[5] Chomsky N. Necessary illusions: Thought control in democratic societies. Boston: South End 1989.

[6] Davis M. Dead cities: And other tales. New York: New Press 2002.

[7] Edsall TB, Edsall MD. Chain reaction: The impact of race, rights, and taxes on American politics. New York: W.W. Norton \& Company 1992.

[8] Halbwachs M. The collective memory. New York: Harper Colophon Books 1980.

[9] Herman E, Chomsky C. Manufacturing consent: The political economy of the mass media. New York: Pantheon 2002.

[10] Bouchard DF, Ed. Michel Foucault. Language, counter-memory, practice: Selected essays and interviews. Ithaca, NY: Cornell University Press 1977.

[11] Gordon C, Ed. Michel Foucault. Power/knowledge: Selected interviews and other writings 1972-1977. New York: Pantheon Books 1980

[12] Rabinow P, Ed. The Foucault Reader. New York: Pantheon Books 1984.

[13] Foucault M. Discipline and punish: The birth of the prison. New York: Penguin Books 1977.

[14] Foucault M. Other spaces. Diacritics 1986; 16: 22-7.

[15] Giddens A. A contemporary critique of historical materialism: power, property, and the state. Berkeley, CA: University of California Press 1981; Vol. 1.

[16] Lefebvre H. The production of space. Smith D, Trans. Cambridge: Blackwell 1991.

[17] Harvey D. The condition of postmodernity. Cambridge, MA: Blackwell 1990.

[18] Harvey D. Spaces of hope. Berkeley: University of California Press 2000.

[19] Bourdieu P. Outline of a theory of practice. Nice R. Trans. New York: Cambridge 1977.

[20] Boyer MC. The city of collective memory: Its historical imagery and architectural entertainments. Cambridge, MA: MIT Press 1994.

[21] Gottdiener M, Lagopoulos A, Eds. Culture, ideology, and the sign of the City. New York: Columbia University Press 1986.

[22] Gottdiener M, Hutchison R. The new urban sociology. $3^{\text {rd }}$ ed. Boulder: CO: Westview Press 2006.

[23] Wohl RR, Strauss AL. Symbolic representations and the urban milieu. Am J Sociol 1958; 63: 523-32.

[24] Davis M. In: Kaplan EA, Ed. Postmodernism and its discontents: Theories, practices. New York: Verso 1988; pp. 79-87.

[25] Davis M. City of quartz. New York: Verso 1990.

[26] Soja E. Postmetropolis: Critical studies of cities and regions. Malden, MA: Blackwell 2000.

[27] Fishman R. The rise and fall of suburbia. New York: Basic Books 1987.

[28] Kleinberg B. Urban America in transformation: Perspectives on urban policy and development. Thousand Oaks, CA: Sage Publications 1995 . 
[29] Jacobs AJ. Inter-local relations and divergent growth: The Detroit and Tokai auto regions, 1969 to 1996. J Urban Aff 2004; 26: 479504.

[30] Hill R. Federalism and urban Policy: The intergovernmental dialectic. In: Swartz T, Peck J, Eds. The changing face of fiscal federalism. New York: M.E. Sharpe 1990.

[31] The DLC. [homepage on the internet]. Washington, DC: The Democratic Leadership Council c2008. [Retrieved October 11, 2008]. Quote paraphrased from About the DLC, p. 1. Available from: http://www.dlc.org

[32] Examples include: Baker P, VandeHei J. A voter rebuke for Bush, the war \& the right. WashPost 2006. November 8: A1; and Schieffer B. The early show. CBS-TV news broadcast. 2006 November 8.

[33] Sage G. Power and ideology in American sport. Champaign, IL: Human Kinetics 1998.

[34] Himmelstein H. Television, myth and the American mind. New York: Praeger 1994.

[35] Seidman S. Contested knowledge: Social theory today. $3^{\text {rd }}$ ed. Malden, MA: Blackwell 2004.

[36] Kunstler J. The geography to nowhere: The rise and decline of America's man-made landscape. New York: Simon \& Schuster 1993.

[37] Dreier P, Mollenkopf J, Swanstrom T. Place matters: Metropolitics for the $21^{\text {st }}$ century. Lawrence, KS: University of Kansas 2001.

[38] Rusk D. Inside game/Outside game. Washington, DC: Brookings Institution Press 1999.

[39] Abelson D. Do think tanks matter? Montreal: McGill-Queen's University Press 2002.

[40] Soley L. Leasing the ivory tower: The corporate takeover of academia. Boston: South End 1995.

[41] Smith J. The idea brokers: Think tanks and the rise of the new policy elite. New York: Free Press 1991.

[42] Rich A. Think tanks, public policy, and the politics of expertise. New York: Cambridge 2005.

[43] Burton B. Battle Tanks: How think tanks shape the public agenda. PRWatch [serial on the Internet]. Fourth Quarter 2005; 12: two pages Available from: http://www.prwatch.org/prwissues/2005Q4/ battletanks

[44] The Heritage Foundation. [homepage on the Internet]. Washington, DC: The Heritage Foundation c2008 [Retrieved October 12, 2008]. Available from: http://www.heritage.org

[45] Strom Thurmond Biography [Internet web site]. Clemson, SC: Strom Thurmond Institute of Government and Public Affairs c2008 [Retrieved October 11, 2008]. Available from: http://www.strom. clemson.edu/strom/bio.html

[46] Rector R. A comprehensive urban policy: How to fix welfare and revitalize America's inner cities. Washington: Heritage Foundation 1993.

[47] AEI [homepage on the Internet]. Washington, DC: American Enterprise Institute for Public Policy Research; c2006 [Retrieved November 18, 2006]. Available from: http://www.aei.org/

[48] Kotkin J. Ideological hurricane. AE Online [serial on the Internet]. 2006; January/February [Retrieved October 30, 2006]. Available from: http://www.taemag.com; quotes on pp. 3,5 .

[49] Hoover Institution [homepage on the Internet]. Stanford, CA: Stanford University c2006 [Retrieved November 16, 2006]. Available from: http://www.hoover.org

[50] Mitchell D. The right to the city: Social justice and the fight for public space. NY: Guilford 2003.

[51] Thomas JM. Redevelopment and race. Baltimore: Johns Hopkins University Press 1997.

[52] Jacobs AJ. Intergovernmental relations and uneven development in the Detroit (U.S.) and Nagoya (Japan) auto regions. Ann Arbor, MI: UMI 1999.

[53] Berry B. Islands of renewal in seas of decay. In: Peterson P, Ed. The new urban reality. Washington, DC: Brookings 1985; pp. 6996.
[54] Berry B. Comment on Elvin K. Wylan and Daniel J. Hammel's islands of decay in seas of renewal. Housing Policy Debate 1999; 10: 783-8.

[55] Aoki K. Race, space, and place. The relation between architecture, modernism, post-modernism, urban planning, and gentrification. Fordham Urban Law J 1993; 20: 669-829.

[56] Gale D. Demographic research on gentrification and displacement J Plann Lit 1985; 1:14-29.

[57] London B, Lee B, Lipston SG. The determinants of gentrification in the U.S: A city-level analysis. Urban Aff Q 1986; 21: 369-87.

[58] Nyden P, Wiewel W, Eds. Challenging uneven development: An urban agenda for the 1990s. New Brunswick, NJ: Rutgers University Press 1991.

[59] Grifith J. Gentrification: Perspectives on the return to the central city. J Plann Lit 1995; 10: 241-55.

[60] Fainstein S. The city builders: Property development in London and New York, 1980-2000. $2^{\text {nd }}$ ed. Lawrence, KS: University of Kansas Press 2001.

[61] Lees L. A reappraisal of gentrification: Towards a geography of gentrification. Prog Hum Geogr 2000; 24: 389-408.

[62] LeGates R, Hartman C. The anatomy of displacement in the United States. In: Smith N, Williams P, Eds. Gentrification of the city. Boston: Allen \& Unwin 1986

[63] Zaravella M. The back-to-the city movement revisited. J Urban Aff 1987; 9: 375-90.

[64] Rothenberg T. And she told two friends: Lesbians creating urban space. In: Bell D, Valentine G, Eds. Mapping desire. New York: Routledge 1995; pp. 165-81

[65] Thomas JM, Danton J. Social diversity and economic development in the Metropolis. J Plann Lit 2006; 21:153-68.

[66] Zukin S. Landscapes of power: Detroit to Disney World. Berkeley: University of California Press 1991.

[67] Kasarda J, Appold S, Sweeny S, Seiff E. Central city migration patterns: Is a turnaround on the horizon? Housing Pol Debate 1997; 8: 307-58.

[68] Wyly E, Hammel D. Islands of decay in seas of renewal: Housing policy and the resurgence of gentrification. Housing Pol Debate 1999, 10: 711-72.

[69] Judd D, Swanstrom T. City politics: The political economy of urban America. New York: Pearson 2006.

[70] Jacobs AJ. Embedded contrasts in race, municipal fragmentation, and planning: Divergent outcomes in the Detroit and greater Toronto-Hamilton regions 1990-2000. J Urban Aff 2009; 31 (April): forthcoming.

[71] Hackworth J. Postrecession gentrification in New York City. Urban Aff Rev 2002; 37: 815-43.

[72] Blakely E, Snyder M. Fortress America: Gated communities in the United States. Washington, DC: Brookings Institution 1997.

[73] U.S. Census Bureau. Current housing reports, Series H150/07. American housing survey for the United States: 2007. Washington, DC U.S. Government Printing Office 2008 (September). Also see the American Housing Survey 2001.

[74] Jacobs AJ. Embedded autonomy and uneven metropolitan development: A comparison of the Detroit and Nagoya auto regions, 1969-2000. Urban Stud 2003; 40: 335-60.

[75] Fong E. A comparative perspective on racial residential segregation: American and Canadian experiences. Sociol Q 1996; 37: 199216.

[76] Blake D. Saving Buffalo from extinction. City Lim 2002; February: 18-25.

[77] Fentress J, Wickham C. Social memory: New perspectives on the past. Cambridge, MA: Blackwell 1992.

[78] Wertsch J. Voices of collective remembering. New York: Cambridge University Press 2002.

[79] Hunker H. Columbus, Ohio: A personal geography. Columbus: Ohio State University 2000.

[80] Brooks D. Patio man and the sprawl people. Weekly Stand 2002; August: 12-29. 